УДК 94(47)+930(571) 050

Исповедников Д. Ю.

\title{
Обзор археографического освещения Гражданской войны на Востоке России
}

Гражданская война в России, как одно из сильнейших потрясений отечественной истории, по-прежнему остается в центре дискуссии о переосмыслении причин и результатов революционных событий, а также о проблеме их полного и объективного изучения. В этой связи важно проследить процесс освоения источниковой базы по теме и понять, как по мере становления археографии менялись подходы к подготовке документальных публикаций, какое место они занимали и занимают в решении научных, политических, образовательных задач, каковы перспективы данной практики.

В настоящей статье изложены результаты диссертационного исследования автора, проведенного на основе комплексного изучения более 100 различных видов и типов документальных публикаций, которые рассматривались в контексте выявления неопубликованных архивных источников по теме в фондах Российского государственного военного архива (РГВА). В ходе работы было исследовано более 200 фондов частей Белой и Красной Армий, госпиталей, лагерей военнопленных, партизанских отрядов. В статье представлены наиболее информативные, на взгляд автора, примеры документальных публикаций, составляющие общую картину введения в научный и общественный оборот источников по теме Гражданской войны на территории восточных областей Российской Империи (Забайкалье, Приамурье, Приморье).

Первое документальное освещение события Гражданской войны на востоке России получили в прессе и материалах местных органов власти, откликнувшихся на выступления контрреволюционных сил весной 1918 г. Брошюры с протоколами заседаний народных съездов знакомили население с позицией различных партийных фракций: большевиков, эсеров, меньшевиков, бурятских националистов. Печатались принятые резолюции по военным вопросам о мобилизации призывных возрастов, о формировании частей Красной армии "для обороны социалистического отечества, от внутренних и внешних врагов" $[18$, c. 14]. Газеты публиковали постановления сельских и станичных собраний о признании советской власти, а также свидетельства о преступлениях отряда есаула Г.М. Семенова, о незаконных реквизициях и расправах над советскими работниками.

С началом интервенции на Дальнем Востоке издание революционной периодики, несмотря на нехватку ресурсов, продолжилось в подполье. По воспоминаниям участника партизанского движения в Хабаровском районе, для набора газеты "Набат" краску заменяли сажей с коптилок, а клише для заставок и иллюстраций вырезали из линолеума. Тем не менее первый номер, вместивший письма и партийные указания, вышел тиражом 500 экземпляров и распространялся в Сучанском, Спасском и Никольском районах. (РГВА. Ф. 40888. Оп. 1. Д. 190. Л. 97) ${ }^{1}$. Решая просветительские задачи, газеты являлись своего рода атрибутом, который подтверждал статус повстанцев как борцов за советскую власть, что было важно в отношениях с обеспечивавшими пополнение и фрураж местными жителями.

Определенное представление о задачах издательского дела в "белом" Забайкалье дает анализ состава фонда типографии при штабе походного атамана Дальневосточных казачьих войск (г. Чита). В 1919 г. здесь наряду с

1 РГВА - Российский государственный военный архив

(ㄷ) Исповедников Д. Ю., 2020

ИСПОВЕДНИКОВ Дмитрий Юрьевич, канд. ист. наук, независимый исследователь (2. Москва). E-mail: mitispo@gmail.com 
частными заказами (бланки, этикетки, входящие и исходящие журналы) печатали подборки японских стихов и обращения интервенционного командования. Тираж "Библии японского солдата и матроса" стал попыткой создать позитивный образ главных союзников атамана Г.М. Семенова. Составитель - подполковник Крылов, прослушавший, как указывалось в выходных данных, 4-х летний курс японского языка в Восточном институте у профрессора Е.Г. Спальвина, - включил в брошюру текст воинской присяги, выдержки из приказа японского императора "О воспитании и обучении армии" 1913 г., из пехотного строевого устава (РГВА. Ф. 39536. Оп. 1. Д. 17. Л. 19-32). В 1920 г. с ослаблением военного и политического положения Читы выросло количество запросов Осведомительного отдела штаба на агитационные летучки и воззвания. В словолитню поступали приказы растиражировать за день 5 тыс. экземпляров "Устава Всероссийской крестьянской партии" (8 марта 1920 г.), 15 тыс. экземпляров "Обращения к казакам Амурцам" и "К казакам-красноармейцам Забайкалья", 20 тыс. стихотворных брошюр с изображением генерал-лейтенанта Г.М. Семенова (май-июнь 1920 г.) (РГВА. Ф. 39536. Оп. 1. Д. 10. Л. 51-52; Д 11. Л. 183).

Важной целью оперативных изданий была пропаганда. Осенью 1918 г. два подобных экземпляра вышли в США, где аргументировалась необходимость отправки на Дальний Восток экспедиционного корпусса для противостояния военнопленным армий Германии и Австро-Венгрии, освобожденным советской властью. Брошюра "Across Siberia toward Liberty!", в основу которой легла литературная переработка доклада капитана Чехословацкого корпуса В. Урбана профрессору Т. Масарику, изображала картину героической борьбы чехов с немецкими и венгерскими интернационалистами на Транссибирской магистрали (РГВА. Ф. 1198/к. Оп. 1. Д. 180, Л. 181-195). Сборник "Тhе German-Bolshevik conspiracy", известный как "документы Э. Сиссона", включил соральсифрицированные польским журналистом А.М. Оссендовским приказы и письма, подтверждавшие версию о финансировании немецким правительством революции в России. Перевод ряда документов сопровождался факсимиле оригинала, научно-справочный аппарат (НСА) содержал примечания, комментарии, а также заключение специальной комиссии о подлинности источников (РГВА. Ф. 1198/к. Оп. 1. Д. 264).

В 1920 г. вышел сборник по теме российско-американских отношений, куда вошли источники, опубликованные в отчетах Сената и Государственного департамента США; переводы из русских газет; материалы полковника Р. Робинса [27]. Отказ от комментирования документов, которым позволили "говорить самим за себя", создавал иллюзию беспристрастности составителей и давал возможность сосредоточить внимание читателя на содержании посланий и писем, удостоверявших нейтралитет США и приверженность сценарию ненасильственного разрешения ситуации в России.

C 1920 г. захваченные материалы о белогвардейских репрессиях и японской оккупации использовали в информационной борьбе журналисты и дипломатические представители Дальневосточной Республики (ДВР). Резонанс публикаций усиливали комментариями и предисловиями (РГВА. Ф. 683. Оп. 1. Д. 15. Л. 78-81). Стратегическую ценность документов понимали и в штабе народно-революционной армии (НРА) ДВР. В частях собирали материал о Гражданской войне: анкетировали личный состав, делали выписки из журналов боевых действий (РГВА. Ф. 8248. Оп. 1. Д. 27; Ф. 11390. Оп. 1. Д. 27). По поручению штаба НРА архивы и библиотеки Барнаула, Омска, Читы, Хабаровска, Нерчинска вели поиск дипломатической переписки за 1917-1921 гг. по установлению русско-китайской границы (РГВА. Ф. 16. Оп. 3. Д. 229. Л. 75, 81, 97, 113).

В 1922 г. полевой штаб главкома ДВР В.К. Блюхера подготовил сборник статей о борьбе за Приморье с выдержками из приказов и листовок противника. Полностью публиковались обращения командования НРА к каппелевцам и генералу B.M. Молчанову, а также "Инструкция комиссии по эвакуации военнопленных и добровольно перешедших белоармейцев" [2]. Декларация мирных намерений во многом объяснялась тяжелым положением НРА. Из рапорта В.К. Блюхера главкому РСФСР С.С. Каменеву, январь 1922 г.: "...командир полка ворует у обывателя свинью и при поимке зарывает ее в землю. Мужская и женская проституция, штабники, падающие с голода в обмороки 
и продающие все от карандаша до секретного документа. Организованные части, угоняющие у крестьян скот под фрлагом конфискации белогвардейского имущества..." (РГВА. Ф. 41109. Оп. 1. Д. 36. Л. 3).

За годы Гражданской войны большой объем политической, экономической, военной документации оказался у частных лиц, писавших на основе собранных коллекций исследовательские труды и популистские сочинения. Постепенно документы передавали Центрархиву и Истпарту, которые выпускали сборники и журнальные публикации, оговаривая способы выявления и степень сохранности материалов [6]. Одновременно, по мере становления архивного дела в советском государстве, доступ к источникам, требовавшим систематизации, ограничивался: в архиве Красной Армии, где штаты в 19191925 гг. варьировались от 3 до 14 чел., до 80\% дел хранились "в ящиках, коробках, кулях" (РГВА. Ф. 29204. Оп. 1. Д. 63).

Особенности публикаторской практики 1920-х гг., децентрализованной, не ограниченной едиными правилами и жестким цензурным контролем, обусловили тематическое разнообразие первых оперативных изданий, которые при низком уровне или отсутствии археографического оформления запечатлели Гражданскую войну на Дальнем Востоке как многостороннее явление. Составители, преследовавшие своей деятельностью самые разные цели, положили начало документальному освещению военных и невоенных аспектов противостояния и уделили внимание большинству вовлечённых в него внутренних и внешних сил.

На протяжении 1930-1950-х гг. со снижением темпов развития археографической практики главным источником по теме оставались воспоминания участников Гражданской войны. Содержательность нарратива определял процесс постепенной "коллективизации памяти" и ее исключения из плоскости индивидуальных размышлений с возможной аналитической составляющей и многообразием сюжетов. При этом репрессии сокращали ряды мемуаристов, а литература о "врагах народа" уничтожалась.

Масштабы кампании красноречиво описал личный врач арестованного и погибшего в Ледортовской тюрьме в ноябре 1938 г. В.К. Блюхера - Ф.С. Малышев. В письме жене маршала Г.Л. Блюхер 10 апреля 1958 г. он сообщал: "Сейчас в Хабаровске... висят портреты Василия Константиновича, но не совсем на него похожие. Говорят, они срисованы с портрета, сохранившегося у одной учительницы" (РГВА. Ф. 41109. Оп. 1. Д. 68. Л. 1об.). Источниковая база лишилась свидетельств многих видных революционеров, хорошо знавших региональную специфику Гражданской войны. Бывший председатель правительства ДВР А.М. Краснощеков (расстрелян в ноябре 1937 г.) в докладе для Центрального дома Красной армии в 1932 г. призвал "остерегаться превращения истории в хвалебный гимн партизанам и партийным организациям". Опытный работник большевистского подполья в Приморье, Забайкалье и на Амуре, он определил дальневосточный этап Гражданской войны как "пестривший уклонами, ложными толкованиями политики центра и множеством тактических ошибок", но в целом являвший "большевистскую борьбу в ленинском духе". А.М. Краснощеков выделял 3 группы местных революционных лидеров, по разным причинам не знакомых с линией центрального советского правительства: "долгое время находившиеся в эмиграции (Любарский, Кушнарев); прибывшие с каторги и ссылки (Губельман, Никифоров); революционный молодняк из рабочих и интеллигенции из партий эсеров и меньшевиков" (РГВА. Ф. 40888. Оп. 1. Д. 175).

Основной задачей изданий являлось отражение руководящей роли партии в победе революции. Как корректировался ракурс, видно при сопоставлении воспоминаний бывшего председателя военно-революционного штаба партизанских отрядов Приамурья Д.И. Бойко-Павлова о хабаровском подполье. В мае 1932 г. на заседании Дальневосточного землячества он описывал разномастный состав съезда, который 10 марта 1919 г. избрал штаб для управления вооруженными силами и политической жизнью области. Доля пролетариата среди делегатов достигала 20-30\%, партийных работников - 20\%. Остальная масса была из крестьян. Присутствовали эсеры, максималисты, авантюристы. Партизанские отряды формировались из крестьянской бедноты и середняков, бывших фронтовиков, добровольцев, и в меньшей степени - из рабочих, местных и попавших на Дальний Восток в качестве ссыльных, или пленных при 
передвижении белогвардейских войск. Производственные ячейки в промышленно отсталом Хабаровске составляли члены союза грузчиков, рабочие морской и речной фрлотилии, депо, окружного арсенала и транспортники (РГВА. Ф. 28361. Оп. 1. Д. 285. Л. 43). В опубликованных рассказах Д.И. Бойко-Павлова акцент сместился, и подполье изображалось "истоком развития победоносного партизанского движения". Малочисленность партийцев компенсировалась высокой организованностью. Боевым авангардом выступали рабочие дружины, тогда как крестьяне обеспечивали их продовольственное и транспортное снабжение. К мартовскому съезду 1919 г. присоединились китайские рабочие, "находившиеся под гнётом ростовщического русского капитала" [3, с. 13-20]. Позднее Д.И. Бойко-Павлов воспоминал о вкладе в дело революции "политического вдохновителя", комиссара Восточного фронта П.П. Постышева. Одним из главных героев его рассказов стал молодой комсомолец Ф. Тропот, который предлагал установить среди партизан дисциплину, "какая введена большевиками в Красной армии" [22, с. 93-124].

Подобный подход исключал освещение герильи как стихийного восстания с грабежами и анархией, осложнявших проведение совместных с регулярной армией операций. В ходе наступления на Читу в апреле 1920 г. военком 1-й бригады Иркутской дивизии НРА констатировал моральный упадок партизан: "Постоянная склонность к митингованию почти в сфрере огня мешает. Нет ни одного надежного отряда для того, чтобы репрессивными мерами вновь поднять дисциплину, а сознательности у них не хватает. Особенно разлагающее действуют партизаны т. Морозова и солдаты 4 батареи, сплошь состоящие из красноармейцев образца 1917 г. Партизанские части, приносящие громадную пользу в борьбе с реакцией, привыкают действовать вне всяких рамок и своей недисциплинированностью влияют на боеспособность частей" (РГВА. Ф. 221. Оп. 1. Д. 423. Л. 10). Страдало и мирное население. В сентябре 1921 г. военком Благовещенского пограничного района назвал "сплошной эпопеей насилий, произвола и уголовщины" службу 4-го кавалерийского пограничного дивизиона: пьянствовавшие бойцы из бывших партизан избили крестьян одного из сел за ношение белых рубах (РГВА. Ф. 18230. Оп. 1. Д. 6. Л. 66-68). В рамках смены политических концепций освещалось участие в революции бурятского населения. С позиций "национального нигилизма" тему раскрывал третий том сборника под редакцией директора НИИ этнических и национальных культур народов Востока CCCP C.M. Диманштейна, включивший 7 документов Бурятского Центрального архива [19, с. 429-443]. В научный оборот вводились материалы за февраль-октябрь 1917 г. о становлении органов национального самоуправления, а также об угнетении коренного населения русскими колонистами, которые захватывали земли бурят, обрекая их на гибель. Четвертый том сборника так и не вышел.

Новая идея "советского патриотизма" формировала уже иную картину общей борьбы народов за власть Советов. Тому, как "закалился и окреп братский союз трудящихся многочисленных национальностей" под партийным руководством был посвящен сборник Истпарта Бурят-Монгольского обкома ВКП(б). Подборку воспоминаний дополнили отдельные материалы военно-революционного штаба Прибайкалья о партизанском движении в 1919-1920 гг. $[4$, c. $173-210]$.

Под влиянием внешнеполитической конъюнктуры формировалось восприятие интервенции. Военную кампанию американских сил на Дальнем Востоке "забыли" на время восстановления отношений с США (1933г.), трактуя события в контексте экономической экспансии, и "вспомнили" о кровопролитии в пропагандистских изданиях периода корейской войны (1950-1953 гг.) [24]. В Америке продолжали активно вводить в оборот дипломатические документы, отражавшие невмешательство в дела России. Широкое освещение события Гражданской войны на Дальнем Востоке получили в серийной публикации, подготовленной сотрудниками Госдепа США [26]. Сборники снабжались внушительным НСА, включавшим предисловие, список опубликованных материалов, именной и предметно-тематический указатели. Дипломатическая переписка американских представителей в регионе освещала развитие противоборства между различными силами, положение мирного населения, состояние экономики. Целый ряд документов передавал негативное отноше- 
ние американцев к главам местных антибольшевистских режимов - Г.М. Семенову и И.П. Калмыкову.

На фоне усиления агрессивной японской политики на Дальнем Востоке в 1930-е гг. выпускались нацеленные на "военизацию" населения массовые издания партизанских рассказов о Гражданской войне в регионе. Создавались схематичные, понятные читателю образы: деревня/станица - "малая родина", японец - "внешний враг", что объясняло нередкое отсутствие в текстах топонимов и имён. С другой стороны, необходимость осмысления того опыта, который советская армия и дипломатия приобрели в противостоянии с Японией в 1920е гг., требовала подготовки научных публикаций. С этой целью под редакцией будущего академика АН СССР И.И. Минца был составлен сборник, который ввел в оборот материалы Центрального архива Октябрьской революции и Центрального архива Красной армии [25]. Источники сопровождались историческими справками и подстрочными примечаниями. Редакторские заголовки указывали вид и время создания документа, должность авторов и адресатов.

Логика развития советской археографиии в 1930-50-е гг. определялась идеологизацией научной сферы, искусственным сужением источниковой базы, упрощением истории. Основной массив публикуемых воспоминаний, которые готовили к выпуску не учёные, а литературные редакторы или участники событий, формировал одностороннее представление о Гражданской войне на Дальнем Востоке как об организованном партработниками выступлении широких народных масс против японских интервентов.

Систему координат советской археографии 1950-1980-х гг. можно условно определить как новые запросы - новые источники - новые сюжеты. В реалиях холодной войны важной задачей было доказать привлекательность коммунистической идеологии, что подразумевало изучение пёстрого состава коалиции революционных сил, объединившихся в 1917-1918 гг., и победы большевиков на политической арене. С постепенным открытием архивов началось углублённое изучение революции в России, в том числе вне военного контекста. Ученым удалось выявить разрозненные материалы первых органов советской власти на Дальнем Востоке [8; 17]. Основательное освещение боевых действий обеспечили крупные сборники Центрального государственного архива Советской армии $[10 ; 23]$.

Общесоюзные и региональные серийные публикации включали материалы по экономической и культурной политике Советов. Использовались отложившиеся в крайкомах и обкомах документы о национализации промышленных предприятий, создании трудовых коммун, реформировании образования. Возрастала доля публикуемых источников небольшевистского происхождения. Для восстановления картины событий 1919-1920 гг. на Дальнем Востоке использовались приговоры белогвардейских военно-полевых судов, приказы карательным отрядам, доклады колчаковской, семеновской контрразведки.

Вместе с тем классовый подход, объяснявший революционную борьбу усилением антагонизма между беднотой и зажиточными слоями населения, искажал представление о межи внутрисословных противоречиях среди казаков, крестьян, бурят и, как следствие, общую картину Гражданской войны. Упрощалось понимание экономических и административных проблем Дальнего Востока, повлиявших на развитие событий. За рамками сборников осталась жизнь Амурского и Уссурийского казачества, стремившихся сохранить дореволюционные привилегии и найти субсидирование после развала Российской Империи. В деловых резолюциях 5-го Чрезвычайного большого войскового круга, прошедшего в октябре 1918 г. в Хабаровске, отмечалось, что казна задолжала Уссурийскому войску более 1,7 млн. руб. и с 1916 г. не отпускала дотаций. В этой связи из ведения Приамурского управления государственных имуществ под контроль Войска вернули основной источник дохода отвод генерала Духовского. Остальные территории, состоявшие до 1913 г. в распоряжении Амурского и Уссурийского казачеств, образовали запасной фонд для нужд растущего населения. С 1 января 1919 г. на 3 года повышалась ежегодная посаженная плата в населённых пункта Войска для иногородних (РГВА. Ф. 39596. Оп. 1. Д. 4. Л. 4об., 5, 7).

В Забайкальском казачьем войске в 1918-1919 гг. шла дискуссия о разделении территории 1-го военного отдела и входящих в неё крестьянских и инородческих поселений на общие и особо казачьи земские участки. Пред- 
седатель Троицкосавской уездной земской управы П.И. Милютин отмечал, что любой из уездов Забайкалья равнялся по величине российской губернии. Земли казаков и крестьян здесь были слишком "черезполосны, смежны и расположены на громадном расстоянии узкой полосою". Сословное разделение органов управления привело бы к работе в одной местности сразу двух учреждений (РГВА. Ф. 39596. Оп. 1. Д. 14. Л. 19-21). Обсуждались преимущества и недостатки уездных и участковых земств. В докладах заместителю войскового атамана Забайкальского войска А.С. Иконникову Нерчинский уездный комиссар утверждал, что участковое земство, отвечая в плане экстерриториальности современному положению деревни, не могло способствовать её хозяйственному и культурному развитию. Находившееся вдали от основных транспортных артерий, малопривлекательное для промышленников, оно было не в состоянии заключать займы на значительный срок, что ввиду низкой платёжеспособности населения являлось главным способом преодоления упадка во врачебном и школьном деле. За годы Гражданской войны в крае закрылось много больниц и школ из-за нехватки работников, а также необеспеченности дровами, тогда как прежде станичники видели "заботу Войскового начальства во всём настолько, что соседнее крестьянское население с завистью смотрело на казаков". Между тем уездному земству, располагавшему кадром специалистов (агрономов, гидротехников, инструкторов), фрабрики и заводы охотно предоставляли сельскохозяйственные орудия, литературу и лекарства. По мнению комиссара, труднореализуемым при переходе к участковым земствам оказалось бы объединение средств от оброчных статей, прибылей с торгов, переправ через реки, рыболовных угодий, ископаемых и пастбищ (РГВА. Ф. 39596. Оп. 1. Д. 14. Л. 16-17).

Региональные сборники освещали помощь жителей ДВР голодающему населению РСФСР в конце 1921 г. - начале 1922 г., тогда как о кризисе в самом "буфере" упоминалось лишь в общих чертах [16, с. 306, 310-313, 362]. Из докладов начальника оперативного управления 2-й Амурской Армии следовало, что урожайность на Амуре падала. В мирное время избыток хлеба составлял около 8 млн. пудов, однако спрос рынка (в первую очередь на золотых приисках) значительно превышал предложение, что вело к увеличению поставок харбинской муки, маньчжурского хлеба. В период боевых действий избыток составлял в среднем 3-4 млн. пуд. и практически полностью сбывался крестьянами в Монголии и Маньчжурии по более выгодным ценам. Крупный рогатый скот и свиньи разводились исключительно для внутреннего потребления и в годы Гражданской войны угонялись на выпас в приграничье. На лето 1921 г. исчисляемое по трудовым карточкам население области достигало 227 868 чел., из которых работали 143310 чел. При норме отпуска на занятых тяжелым трудом (76 250 чел.) - 1 пуда муки, и на стариков и детей (84 558 чел.) - 30 фрунтов и на нетрудящихся - 20 фрунтов ежемесячно области требовалось 168824 пуд. муки, 63309 пуд. мяса, 33764 пуд. круп (РГВА. Ф. 170. Оп 1. Д. 66. Л. 54об.-55).

Трансграничные публикации по истории интернационального движения героизировали военнопленных Первой мировой войны, примкнувших к русской революции. Жизнь гораздо более многочисленной, но политически индифрферентной массы их соотечественников осталась без внимания [11]. Целый ряд фрактов не вписался в хронологию и тематику советско-монгольских сборников о борьбе монгольского народа за независимость и изгнание белогвардейских частей. Через призму дипломатической переписки отношения между странами были показаны как идиллические, лишенные прагматизма. О переговорах монгольских революционеров с советскими работниками в конце 1920 г. и взятии Урги Р.Ф. Унгерном в феврале 1921 г. сообщалось в объемных примечаниях к документам [13].

Снижался цензурный контроль при издании воспоминаний. С оговоркой в предисловии или комментариях, допускались идеологические неточности. Встречались и подобные рассуждения: "в германскую войну был в нашей части такой офицер, что отец родной, потом в револющию он с народом пошел и даже дрался с нами в Питере против буржуев" [14, с. 389]. Выходила литература о реабилитированных жертвах репрессий. В личном фонде бывшего главкома НРА И.П. Уборевича сохранились материалы, отражающие ход работы над книгой о нем [21]. Поскольку спецфонды архивов и библиотек стали 
доступны лишь после XXII съезда КПСС (1961г.), многие сведения уточнялись у родственников и сослуживцев командарма (РГВА. Ф. 41132. Оп. 1. Д. 35,43$)$.

Со второй половины 1950-х гг. советская археография активно развивалась на региональном, всесоюзном, международном направлениях. При сохранении марксистско-ленинской методологии исследований на первый план выходили малоизученные военные и невоенные сюжеты дальневосточного этапа Гражданской войны. С расширением источниковой базы, тематики и географиии документальных публикаций усложнялась их структура, видовой и типовой состав, увеличивались компоненты НСА.

В отечественной эдиционной практике первой половины 1990-х гг. прослеживались параллели с тенденциями 1920-х гг. Резкая смена тематики и временное падение уровня археографического оформления изданий, где НСА заменяли вступительные статьи, а документы приводились без заголовков и легенд, объяснялись желанием оперативно ввести в оборот малоизвестные материалы [9].

В дальнейшем при постепенном рассеивании догматизма началось развитие археографии по курсу реконструкции и новации. С учетом достижений советской науки и открывшихся возможностей новое освещение получила интервенция на Дальнем Востоке [7]. Продолжилось сотрудничество с архивами Монголии [20], выявление источников о выдающихся революционерах [15].

Рассекречивание фондов Коминтерна дало импульс изучению политики СCCP в отношении стран Азии. При этом потенциал трансграничной публикаторской деятельности на данном направлении не реализован. Сохранившиеся в фондах РГВА документы иностранного происхождения указывают на перспективность исследования архивов Японии, Китая, Южной Кореи, где могут храниться материалы по истории Гражданской войны на Дальнем Востоке [12].

При освещении истории Белого движения первоначально в расчете на привлечение массового читателя особое внимание уделялось одиозным деятелям. Один из них - генерал-лейтенант Р.Ф. Унгерн, чьё имя использовалось в пропагандистских целях на протяжении всего развития советской археографоии. Попытку развеять мифы, связанные с бароном, предпринял востоковед С.Л. Кузьмин, который выявил в отечественных и зарубежных архивах крупный комплекс неизвестных документов [1].

Сегодня российские археографы стараются придерживаться в своей работе объективного подхода, тщательно проводят отбор и оформление источников. Одним из достоинств современных публикаций является использование редких фотографий. Выходят и целые сборники иллюстративных материалов [5]. Вместе с тем персонификация Белого движения посредством документального освещения жизни его идейных лидеров оставляет без должного внимания положение рядовых солдат, офицеров младшего и среднего звена. Ценным источником, раскрывающим взгляды части из них на события Гражданской войны и мотивы службы, с учетом общей "оправдательной" риторики, являются опросные листы перебежчиков и военнопленных. Известный советский военный летчик, служивший в различных "белых" авиачастях, прапорщик А.Г. Дедюлин, который 20 июля 1920 г. перелетел в расположение 5-й Армии, в своих показаниях сообщал: "будучи мобилизован, сначала я хотел работать, но потом, когда власть перешла к Дерриктории, а потом к Колчаку, я стал ловчиться, для того чтобы не попасть на фронт и не участвовать в гражданской войне, результатом чего и явилась моя служба в Чешской школе и во Владивостоке в 8 авиаотряде формирующемся.

После переворота в январе 1920 г., когда власть во Владивостоке фрактически перешла к коммунистам, а была под фолагом Земства, моим решением было остаться в Дальне-Восточной школе, сохранить имущество и работать там. После выступления японцев 4-5 апреля, когда имущество школы было опечатано и разграблено японцами, и школа перестала фуннкционировать, моим решением было перелететь к красным. Боясь в случае перелета репрессий со стороны красных за службу в белой армии, т. к. об этом распространялись всевозможные слухи, я решил ехать во Владивосток и выяснить подробнее. 15/VI виделся там с уполномоченным Советского правительства тов. Виленским-Сибиряковым, заручившись от него рекомендательной бу- 
мажкой о неприкосновенности личности, отправился в Спасское, получил от Начальника школы нужные бумаги /увольнительное свидетельство в Харбин на 10 суток/ прибыл в Харбин и явился к генералу Филатьеву, вербующему офицеру заявил о желании служить Семенову. 13 июля 1920 г. был отправлен к Семенову..." (РГВА. Ф. 185. Оп. З. Д. 1094. Л. 119-120).

Сведения о службе в антибольшевистских войсках выяснялись при уточнении биографий членов и кандидатов в члены РКП(б). Из протокола собрания коммунистической ячейки при Благовещенском уездном Военном управлении в связи с партийной чисткой (апрель 1922 г.), обсуждение И.А. Устинова:

"...- Охотно ли вы пошли на службу к Калмыкову?

- Да, пошел на службу охотно, т.к. знал, что все же я останусь жив, и если отправят дальше меня в лагеря пленных, то там мне не выжить.

- Знали-ли, что отец ваш находится в тайге в партизанах, а вы служите у Колчака?

- Да, это я хорошо знал.

- Почему вы не ушли в тайгу вместе с отцом?

- У меня не было средств к существованию, потому что отец ушел в тайгу, я остался кормить семейство..." (РГВА. Ф. 25890. Оп. 1. Д. 21. Л. 1414об.).

Интерес представляют материалы военных трибуналов. В письме распорядительному заседанию военного трибунала при 2-й Приамурской стрелковой дивизии от 15 мая 1923 г. о жизни во время Гражданской войны рассказал заключённый Хабаровского Губернского исправительного дома К.Г. Малков. Он был осуждён в январе 1923 г. на 6 лет и 8 месяцев со строгой изоляцией за службу в войсках И.П. Калмыкова с ноября 1919 г. по февраль 1920 г. и М.К. Дитерихса с фревраля по октябрь 1922 г. по добровольному вступлению (ст. 60 УК РСФСР). Призывая пересмотреть судебное решение, К.Г. Малков писал:

"Весной 1919 г. оканчиваю Высшее начальное училище и поступаю в Хабаровское губернское казначейство и служу там до ноября 1919 г. Переворот 1918 г., вход Калмыкова, встреча его некоторыми жителями как избавителя, бросанье ему под ноги цветов, устраиваемые в честь его обеды, ужины, вечера, балы, концерты и т.д., безусловно, также произвели на меня впечатление. И осенью 1919 г. я, заручившись принципиальным согласием родителей и братьев, а самое главное, желая стать "военным", - поступаю в штаб стрелкового батальона, вольнонаемным писарем. В последствии батальон развёртывается в бригаду, и я до 1 февраля 1920 г. продолжаю служить там. С 1 февраля открылось Военное училище Калмыкова, и многие мои одноклассники по училищу поступают туда и некоторые предлагают мне перевестись в Военное училище. Не умея что-нибудь делать самостоятельно, не видя со стороны родных препятствий к поступлению, а главное, имея желание стать "военным", а также желая закончить среднее образование - поступаю...

12 февраля получаем приказание собираться. На наш вопрос - "куда?" отвечают - "в экспедицию". Начались приготовления получка шуб, рукавиц, шапок, катанок, ватного обмундирования и т.д., и в ночь на 13 /II выступаем из Хабаровска вверх по р. Уссури. Пройдя до Красной Речки, я узнаю, что мы отступаем от Хабаровска, что мы обмануты. С этого момента начались мученья, стужа, сон под открытым небом при 25 градусном морозе, перестрелки с партизанами, в которых я не участвовал, потому что не умел держать винтовку. В таком виде дошли до поселка Кукелево. У меня была все время мысль уехать обратно в Хабаровск, но после того, как расстреляли 7 человек, которые тоже собирались убежать, мысль о побеге больше не приходила в голову. От Кукелево пошли по снеговой пустыне в Китай... (РГВА. Ф. 24467. Оп. 1. Д. 110. Л. 9; Д. 108. Л. 25-55).

Отдельные следственные дела отсылают к современности в связи с пересмотром их военной прокуратурой и реабилитацией бездоказательно осуждённых. Из сохранившихся протоколов допросов, характеристик обвиняемых, потерпевших, свидетелей можно почерпнуть сведения о повседневной жизни населения, о взаимоотношениях и настроениях в обществе. Введение данных материалов в научный оборот в форме таблиц или регестов позволит выделить наиболее важную информацию. 
Изучение итогов археографического освещения истории Гражданской войны на Дальнем Востоке позволяет сделать несколько заключений. На каждом историческом этапе картина Гражданской войны, как сложного явления, сочетающего военные и невоенные аспекты, меняется под влиянием научных и ненаучных фракторов. Совокупность документальных публикаций разных видов и типов, преследующих разные цели и подготовленных на основе разных методологических подходов, не формирует полного представления о революционных событиях. Выявление новых документов по малоизученным сюжетам тематики ставит вопрос о приёмах их введения в научный оборот. мым:

При дальнейшей археографической работе представляется необходи-

- завершить перевод изданий по истории Гражданской войны в электронный формат для создания единой общедоступной базы опубликованных источников;

- разработать концепцию обобщающей серии публикаций "Гражданская война в России по фондам отечественных архивов", в рамках которой каждый федеральный и региональный архив презентует сборник, отражающий специфику хранимых документов по теме;

- активизировать сотрудничество с иностранными архивами для выявления хранящегося за рубежом комплекса материалов, связанных с историей Гражданской войны на Дальнем Востоке.

\section{Литература}

1. Барон Унгерн в документах и мемуарах / сост. и ред. С.Л. Кузьмин. М.: Товарищество научных изданий КМК, 2004. 661 с.

2. Борьба за Хабаровск. Чита: Государственная тип., 1922. 112 с.

3. Борьба за Советы на Дальнем Востоке / сост. П. Никифоров, И.В. Слинкин, Б.Н. Мельников. М.: Госиздат, 1932. 94 с.

4. Бурят-Монголия в борьбе за Советы. Сборник воспоминаний и документов / под ред. М. Гудошникова, И. Кузнецова, Ф. Шулунова. Иркутск: Партиздат, восточносибирское краевое отделение, 1933. 216 с.

5. Гражданская война в России в фотографиях и кинохронике. 1917-1922 / отв. ред. Е.Е. Колоскова. М.: Кучково поле, 2018. 584 с.

6. Дальистпарт. Сборник материалов по истории революционного движения на Дальнем Востоке. Владивосток: Книжное дело, 1923. Кн. 1.286 с.

7. Дальневосточная политика Советской России (1920-1922 гг.) / сост. М. П. Малышева, В. С. Познанский. Новосибирск: Сибирский хронограф, 1995. 370 с.

8. Дальсовнарком. 1917-1918 гг. / под ред. В.С. Флерова, сост. Г.П. Колбин. Хабаровск: Хабаровское кн. изд., 1969. 373 с.

9. Дело не получило благословения Бога / лит. композиция, литправка и прилож. Г.С. Чечулиной. Хабаровск: Книжное издательство, 1992. 368 с.

10. И на Тихом океане: НРА ДВР в освобождении Приамурья и Приморья / сост. В.О. Дайнес, ред. В.О. Дайнес, Т.Ф. Каряева, М.В. Стеганцев. Иркутск: Восточносибирское кн. изд., 1988. 360 с.

11. Исповедников Д.Ю. Военнопленные Первой Мировой войны в жизни Сибири и Дальнего Востока 1917-1920 гг. // II Международная архивная конференция "Первая Мировая война и ее последствия для военнопленных и гражданских лиц": избранные материалы. М.: МККК, 2019. С. 25-31.

12. Исповедников Д.Ю. Гражданская война на Дальнем Востоке в публикациях источников иностранного происхождения // Исторические документы и актуальные проблемы археографии, источниковедения, российской и всеобщей истории нового и новейшего времени: сборник материалов седьмой международной конференции молодых ученых и специалистов "Clio-2017" / гл. ред. А.К. Сорокин, отв. ред. С.А. Котов. М., 2017. C. 179-183.

13. Исповедников Д.Ю. Международные аспекты Гражданской войны на Дальнем Востоке по документам РГВА // Материалы международной научно-практической конференции "История Гражданской войны в России 1917-1922 гг.". М.: ЦМВС РФ, 2016. C. $146-153$.

14. Как мы боролись за власть Советов в Иркутской губернии / сост. Г.А. Вендрих. Иркутск: Иркутское книжное издательство, 1957. 558 с.

15. Луцкий Е.А., Мухачёв Б.И. Алексей Луцкий: историко-биографический очерк (1883-1920 гг.). Владивосток: Дальнаука, 2012. 276 с.

16. Октябрь на Амуре / сост. Э.В. Казанская, Л.Г. Штилерман, введ. В.П. Малышева. Благовещенск, 1961. 456 с. 
17. Подвиг Центросибири / сост. В.Т. Агалаков. Иркутск: Восточносибирское кн. изд., 1986. 477 с.

18. Протоколы заседаний съезда представителей крестьян, рабочих, казаков и бурят Забайкальской области 24 марта - 5 апреля 1918 г. Чита. 1918. 112 с.

19. Революция и национальный вопрос. Документы и материалы по истории национального вопроса в России и ССCР в XX веке / сост. С.М. Диманштейн. М.: Изд. коммун. академии, 1930. Т. III. 467 с.

20. Российско-монгольское военное сотрудничество (1911-1946) / сост. И.И. Кудрявцев. М.; Улан-Удэ: Полиграфический комплекс ФГОУ ВПО ВСНАГИ, в 2 Т., 2008. T. 1.349 c.

21. Севастьянов В.И., Егоров П.Я. Командарм первого ранга. М.: Политиздат, 1966. 215 c.

22. Таежные походы. Сборник эпизодов из истории Гражданской войны на Дальнем Востоке. М.: Госиздат, 1936. 503 с.

23. Шли дивизии вперед. 1920-1921 гг. Народно-революционная армия в освобождении Забайкалья. Иркутск: Восточносиб. кн. изд., 1987. 488 с.

24. Этого не забыть! (сборник воспоминаний трудящихся Приморского края о кровавых злодеяниях американских интервентов 1918-1920) / сост. А.А. Вахов. Владивосток: Примиздат, 1951. 112 с.

25. Японская интервенция 1918-1922 гг. в документах / сост. И.И. Минц. М.: Центрархив, 1934. 235 с.

26. Papers relating to the foreign relations of the United States. 1918. Russia. W.: Government Printing Office, In 3 vols. Vol. I., 1931. 754 p., Vol. II., 1932. 887 p., Vol. III., 1932. 330 p.

27. Russian-american relations. March, 1917 - March, 1920 / comp. and ed. by C.K. Cumming and W.W. Pettit. N.Y.: Harcourt, Brace, 1920. 375 p.

\section{Транслитерация по ГОСТ 7.79-2000 Система Б}

1. Baron Ungern v dokumentakh i memuarakh / sost. i red. S.L. Kuz'min. M.: Tovarishhestvo nauchnykh izdanij KMK, 2004. 661 s.

2. Bor'ba za KHabarovsk. CHita: Gosudarstvennaya tip., 1922. 112 s.

3. Bor'ba za Sovety na Dal'nem Vostoke / sost. P. Nikiforov, I.V. Slinkin, B.N. Mel'nikov. M.: Gosizdat, 1932. 94 s.

4. Buryat-Mongoliya v bor'be za Sovety. Sbornik vospominanij i dokumentov / pod red. M. Gudoshnikova, I. Kuznetsova, F. SHulunova. Irkutsk: Partizdat, vostochnosibirskoe kraevoe otdelenie, 1933. $216 \mathrm{~s}$.

5. Grazhdanskaya vojna v Rossii v fotografiyakh i kinokhronike. 1917-1922 / otv. red. E.E. Koloskova. M.: Kuchkovo pole, 2018. 584 s.

6. Dal'istpart. Sbornik materialov po istorii revolyutsionnogo dvizheniya na Dal'nem Vostoke. Vladivostok: Knizhnoe delo, 1923. Kn. 1. 286 s.

7. Dal'nevostochnaya politika Sovetskoj Rossii (1920-1922 gg.) / sost. M. P. Malysheva, V. S. Poznanskij. Novosibirsk: Sibirskij khronograf, 1995. 370 s.

8. Dal'sovnarkom. 1917-1918 gg. / pod red. V.S. Flerova, sost. G.P. Kolbin. KHabarovsk: KHabarovskoe kn. izd., 1969. 373 s.

9. Delo ne poluchilo blagosloveniya Boga / lit. kompozitsiya, litpravka i prilozh. G.S. CHechulinoj. KHabarovsk: Knizhnoe izdatel'stvo, 1992. $368 \mathrm{~s}$.

10. I na Tikhom okeane: NRA DVR v osvobozhdenii Priamur'ya i Primor'ya / sost. V.O. Dajnes, red. V.O. Dajnes, T.F. Karyaeva, M.V. Stegantsev. Irkutsk: Vostochnosibirskoe kn. izd., 1988. 360 s.

11. Ispovednikov D.YU. Voennoplennye Pervoj Mirovoj vojny v zhizni Sibiri i Dal'nego Vostoka 1917-1920 gg. // II Mezhdunarodnaya arkhivnaya konferentsiya "Pervaya Mirovaya vojna i ee posledstviya dlya voennoplennykh i grazhdanskikh lits": izbrannye materialy. M.: MKKK, 2019. S. 25-31.

12. Ispovednikov D.YU. Grazhdanskaya vojna na Dal'nem Vostoke v publikatsiyakh istochnikov inostrannogo proiskhozhdeniya // Istoricheskie dokumenty i aktual'nye problemy arkheografii, istochnikovedeniya, rossijskoj i vseobshhej istorii novogo i novejshego vremeni: sbornik materialov sed'moj mezhdunarodnoj konferentsii molodykh uchenykh i spetsialistov "Clio-2017" / gl. red. A.K. Sorokin, otv. red. S.A. Kotov. M., 2017. S. 179-183.

13. Ispovednikov D.YU. Mezhdunarodnye aspekty Grazhdanskoj vojny na Dal'nem Vostoke po dokumentam RGVA // Materialy mezhdunarodnoj nauchno-prakticheskoj konferentsii "Istoriya Grazhdanskoj vojny v Rossii 1917-1922 gg.". M.: TSMVS RF, 2016. S. $146-153$.

14. Kak my borolis' za vlast' Sovetov v Irkutskoj gubernii / sost. G.A. Vendrikh. Irkutsk: Irkutskoe knizhnoe izdatel'stvo, 1957. $558 \mathrm{~s}$.

15. Lutskij E.A., Mukhachyov B.I. Aleksej Lutskij: istoriko-biograficheskij ocherk (1883-1920 gg.). Vladivostok: Dal'nauka, 2012. 276 s. 
16. Oktyabr' na Amure / sost. EH.V. Kazanskaya, L.G. SHtilerman, vved. V.P. Malysheva. Blagoveshhensk, 1961. $456 \mathrm{~s}$.

17. Podvig TSentrosibiri / sost. V.T. Agalakov. Irkutsk: Vostochnosibirskoe kn. izd., 1986. $477 \mathrm{~s}$.

18. Protokoly zasedanij s"ezda predstavitelej krest'yan, rabochikh, kazakov i buryat Zabajkal'skoj oblasti 24 marta - 5 aprelya 1918 g. CHita. 1918. 112 s.

19. Revolyutsiya i natsional'nyj vopros. Dokumenty i materialy po istorii natsional'nogo voprosa v Rossii i SSSR v XX veke/ sost. S.M. Dimanshtejn. M.: Izd. kommun. akademii, 1930. T. III. $467 \mathrm{~s}$.

20. Rossijsko-mongol'skoe voennoe sotrudnichestvo (1911-1946) / sost. I.I. Kudryavtsev. M.; Ulan-Udeh: Poligraficheskij kompleks FGOU VPO VSNAGI, v 2 T., 2008. T. 1. $349 \mathrm{~s}$. $215 \mathrm{~s}$.

21. Sevast'yanov V.I., Egorov P.YA. Komandarm pervogo ranga. M.: Politizdat, 1966.

22. Taezhnye pokhody. Sbornik ehpizodov iz istorii Grazhdanskoj vojny na Dal'nem Vostoke. M.: Gosizdat, 1936. 503 s.

23. SHli divizii vpered. 1920-1921 gg. Narodno-revolyutsionnaya armiya v osvobozhdenii Zabajkal'ya. Irkutsk: Vostochnosib. kn. izd., 1987. 488 s.

24. EHtogo ne zabyt!! (sbornik vospominanij trudyashhikhsya Primorskogo kraya o krovavykh zlodeyaniyakh amerikanskikh interventov 1918-1920) / sost. A.A. Vakhov. Vladivostok: Primizdat, 1951. 112 s.

25. YAponskaya interventsiya 1918-1922 gg. v dokumentakh / sost. I.I. Mints. M.: TSentrarkhiv, 1934. $235 \mathrm{~s}$.

26. Papers relating to the foreign relations of the United States. 1918. Russia. W.: Government Printing Office, In 3 vols. Vol. I., 1931. 754 p., Vol. II., 1932. 887 p., Vol. III., 1932. 330 p.

27. Russian-american relations. March, 1917 - March, 1920 / comp. and ed. by C.K. Cumming and W.W. Pettit. N.Y.: Harcourt, Brace, 1920. 375 p.

\begin{abstract}
Исповедников Д. Ю. Обзор археографического освещения Гражданской войны на Востоке России.

В статье анализируются итоги освещения Гражданской войны на Востоке России в отечественной и зарубежной археографической практике на протяжении 1920 -х - 2000-х гг. Изложены результаты комплексного изучения более 100 документальных публикаций, а также выявления неопубликованных материалов в фондах Российского государственного военного архива. Сделаны выводы об особенностях источниковой базы и процессе ее освоения на каждом историческом этапе. Выделены сюжеты, неполно отраженные в сборниках, и разновидности документов, которые редко использовались составителями. Определены приоритетные направления дальнейшего освещения темы с учетом общих перспектив практической археографии.
\end{abstract}

Ключевые слова: Гражданская война в России, Дальний Восток, археографбия, документальные публикации, архивные источники

Ispovednikov D. Yu. Review of archaeographic coverage of the Civil War in the East of Russia.

The article analyzes the results of the coverage of the Civil War in the East of Russia in domestic and foreign archaeographic practice during the 1920s - 2000s. There are presented the results of a comprehensive study of more than 100 documentary publications, as well as of identification of unpublished materials in the funds of the Russian State Military Archive. Conclusions about the features of the source base and the process of its development at each historical stage are drawn. The plots, incompletely reflected in the collections, and varieties of documents rarely used by compilers are highlighted. There are identified priority areas for further coverage of the topic, taking into account the general perspective of practical archeography.

Key words: Civil War in Russia, the Far East, archeography, documentary publications, archival sources

Для цитирования: Исповедников Д. Ю. Обзор археографического освещения Гражданской войны на Востоке России // Ойкумена. Регионоведческие исследования. 2020. № 4. C. 54-64. DOI: 10.24866/1998-6785/2020-4/54-64

For citation: Ispovednikov D. Yu. Review of archaeographic coverage of the Civil War in the East of Russia // Ojkumena. Regional researches. 2020. № 4. P. 54-64. DOI: 10.24866/1998$6785 / 2020-4 / 54-64$ 